\title{
Growth-stage-specific crop coefficient and consumptive use of Capsicum chinense using hydraulic weighing lysimeter
}

\author{
O.D. Raphael ${ }^{\mathrm{a}, *}$, K. Ogedengbe ${ }^{\mathrm{b}}$, J.T. Fasinmirin ${ }^{\mathrm{a}}$, D. Okunade ${ }^{\mathrm{a}}$, I. Akande ${ }^{\mathrm{a}}$, A. Gbadamosi \\ a Department of Agricultural and Biosystems Engineering, Landmark University, Omuaran, Nigeria \\ ${ }^{\mathrm{b}}$ Department of Agricultural and Environmental Engineering, University of Ibadan, Nigeria \\ ${ }^{\mathrm{c}}$ Landmark University Teaching and Research Farms, Nigeria
}

\section{A R T I C L E I N F O}

\section{Keywords:}

Capsicum chinense

Crop factor

Evapotranspiration

Water use

\begin{abstract}
A B S T R A C T
This research was conducted to determine growth stage-specific crop coefficient (Kc) and Consumptive Use (CU), for Capsicum chinense (Ata rodo) grown under irrigation in Omu-Aran, North central Nigeria. Daily CU and growth stagespecific crop coefficient Kc for Capsicum chinense was measured using a developed and calibrated hydraulic weighing lysimeter over 2 consecutive dry seasons (2015/16 and 2016/17). The values of CU and growth stage-specific Kc obtained were compared to that estimated using CROPWAT 8.0 and with existing Food and Agricultural Organization (FAO) Kc values for bell pepper. The Kc values determined over the growing seasons varied from 0.32 to $0.7,1.02$ to 1.45 and 0.76 to 0.9 representing $\mathrm{Kc}$ initial, $\mathrm{Kc}$ mid-season and $\mathrm{Kc}$ late season $\left(\mathrm{Kc}_{\mathrm{ini}}, \mathrm{Kc}_{\mathrm{mid}}\right.$ and $\mathrm{Kc}_{\mathrm{end}}$ ), respectively. These $\mathrm{Kc}$ varied significantly $(\mathrm{P}<0.05)$ from FAO established Kc values. The observed Kc was validated using relevant statistical methods. The seasonal CU of Capsicum chinense was $580.01 \pm 54 \mathrm{~mm}$, while the reference evapotranspiration increased from $3.26 \mathrm{~mm}_{\text {day }}{ }^{-1}$ in October to $4.19 \mathrm{~mm}$ day $^{-1}$ in February. The crop factor increased from 0.7 in October to attain its peak of 1.45 in January, but decreased to 0.9 during crop senescence in February. Likewise, the daily crop water need was $2.28 \mathrm{~mm}_{\text {day }}{ }^{-1}$ in October but reached its peak of $5.82 \mathrm{~mm}_{\text {day }}{ }^{-1}$ in January and thereafter decreased to $3.77 \mathrm{~mm} \mathrm{day}^{-1}$ in February. Mean monthly water need of Capsicum chinense pepper was $68.36 \mathrm{~mm} \mathrm{month}^{-1}$ in October. The water need of crop rose to its peak of $166.32 \mathrm{~mm} \mathrm{month}^{-1}$ in December, and thereafter declined to $113.13 \mathrm{~mm} \mathrm{month}^{-1}$ in February It is inferred that the application of growth stage-specific Kc will assist in irrigation management and would serve as useful guide for precise water applications for areas around Omu-Aran as it differs from region to region.
\end{abstract}

\section{Introduction}

Water plays an important role in crop production. Irrigation scheduling generally determines the time of the next watering event and the amount of water to apply. It is a decision that varies from one agro-ecological zone to the other especially in the sub-Sahara Africa where a wide range of variation is observed within a given region. Understanding crop water requirement needs is inevitable for irrigation scheduling and agricultural water management because of the ever increasing population of the world, the need to produce more food per drop of water, dwindling water supply for agriculture and increasing domestic and industrial water demands. The consumptive use is defined as the amount of water needed to meet water loss to the atmosphere through evapotranspiration (Allen et al., 1998). There is the need to improve the water use efficiency of crops for both rain-fed and irrigated agriculture in Nigeria, due to the recent changes in climatic and weather condition across the different agro-ecological zones in Nigeria. Therefore, the first step toward sound management of the scarce water resources in all regions is accurate estimation of the water needs and crop coefficient. The ability to estimate evapotranspiration and predict crop water requirements will improve crop water-use efficiency, improve crop productivity and consequently save water for other purposes (Fisher, 2012).

Capsicum spp. is one of the important vegetable crops in Nigeria. It is not only used as vegetable but an important spice/condiment in almost all meals in the sub-Saharan Africa. Growing capsicum in field condition is very challenging because it is much sensitive to both insufficient and excess supply of water and ambient temperature. The crop is generally grown during dry season in order to make water management task convenient. The photograph of a typical Capsicum chinense is shown in Plate 1.

Weighing lysimeters have been used for many years to measure and study water use, to calibrate reference ET methods for a local areas, and to develop crop-coefficients for specific crops (Ko et al., 2009; Igbadun, 2012; Abrisquetaa et al., 2013; Fasinmirin et al., 2015; Abedinpour, 2015). Lysimeters are employed to measure reference crop evapotranspiration $\left(\mathrm{ET}_{\mathrm{o}}\right)$ and crop evapotranspiration (ETc) directly by detecting changes in the weight of the soil crop unit and relating it to consumptive use (Abedinpour, 2015). $\mathrm{ET}_{\mathrm{c}}$ is determined by the crop coefficient approach whereby the effects of the

\footnotetext{
* Corresponding author.

E-mail address: raphael.davids@lmu.edu.ng (O.D. Raphael).
} 

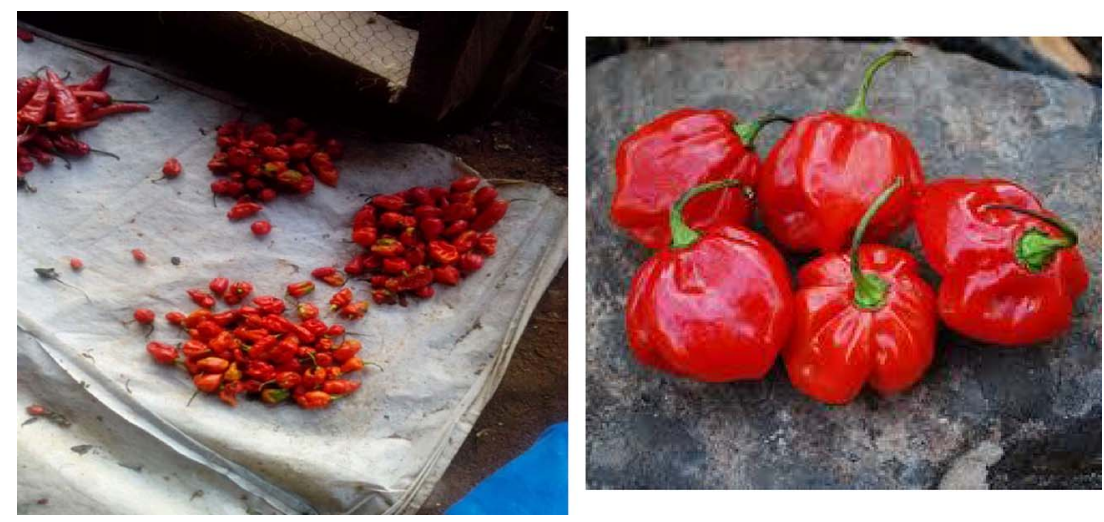

Plate 1. Pictures of a typical Capsicum chinense.

various weather conditions are incorporated into $\mathrm{ET}_{\mathrm{o}}$ and the crop characteristics into the crop coefficient (Kc). Weather data are used to compute $\mathrm{ET}_{\mathrm{o}}$ via equations such as the ASCE Penman-Monteith (ASCE-EWRI, 2005). $\mathrm{Kc}$ value is obtained from the ratio of $\mathrm{ET}_{\mathrm{c}}$ and $\mathrm{ET}_{\mathrm{o}}$. The time-averaged single $\mathrm{Kc}$ is used for irrigation planning and design, irrigation management, basic irrigation schedules and real time irrigation scheduling for non- frequent water applications (surface and sprinkler irrigation) (Allen et al., 1998). The time-averaged single Kc is valid and given in Eq. (1)

$\mathrm{ET}_{\mathrm{c}}=\mathrm{K}_{\mathrm{c}} \mathrm{ET}_{\mathrm{o}}$

where: $\mathrm{ET}_{\mathrm{c}}$ : Crop evapotranspiration $\left[\mathrm{mm} \mathrm{d}^{-1}\right]$, Kc: Single crop coefficient [dimensionless], and $\mathrm{ET}_{\mathrm{o}}$ : Reference crop evapotranspiration $\left[\mathrm{mm} \mathrm{d}^{-1}\right]$.

FAO published Kc values of different crops vary from place to place and season to season (Allen et al., 1998). The values are commonly used in places where locally determined data are not available. The experimental determination of ETc of different crops under given climatic conditions is important. No known study exist on Consumptive Use of Capsicum chinense and other arable crops in the study area using hydraulic weighing lysimeter. Several authors have provided guidelines for crop water requirement in other agro-ecological zones close to the study area (Adeniran et al., 2010; Igbadun, 2012; Fasinmirin et al., 2015). FAO-56 (Allen et al., 1998) contains typical values for $\mathrm{Kc}_{\mathrm{ini}}$, $\mathrm{Kc}_{\mathrm{mid}}$ and $\mathrm{Kc}_{\mathrm{end}}$ for various agricultural crops. Single (time-averaged) crop coefficients, Kc, and mean maximum plant heights for nonstressed, well-managed crops in sub humid climates (RHmin $\approx 45 \%$, $\mathrm{u} 2 \approx 2 \mathrm{~m} / \mathrm{s}$ ) for use with the FAO Penman-Monteith ETo was also tabulated.

The research was aimed at determining growth-stage specific crop coefficient and consumptive use for Capsicum chinense using a hydraulic weighing lysimeter in Omu-Aran, North central Nigeria. The results were also compared with those obtained by applying FAO recommended crop data.

\section{Materials and methods}

\subsection{Site description and experimental setup}

This study was carried out at the Teaching and Research Farm of Landmark University, Omu-Aran. The location is on latitude $8^{\circ} 8^{\prime} 00^{\prime \prime} \mathrm{N}$, longitude $5^{\circ} 6^{\prime} 00^{\prime \prime} \mathrm{E}$, and altitude $564 \mathrm{~m}$ above mean sea level. The site is located in the derived savanna ecological zone of Nigeria. The rainfall pattern is bimodal with peaks in June and October. The total annual rainfall in the area was about $1227 \mathrm{~mm}$ in 2015 with mean air temperature of $26.2^{\circ} \mathrm{C}$ and mean relative humidity of $75.9 \%$. In 2016, the total annual rainfall in the area was $1240 \mathrm{~mm}$ with mean air temperature of $27.3^{\circ} \mathrm{C}$ and mean relative humidity of $78.5 \%$. The soil in the site of the experiment is an Alfisol classified as Oxic Hap-lustalf or Luvisol (Adekiya et al., 2015).

The climate is of the study area is a tropical maritime with lengthy rainy season. The area is characterized by moderate weather with an annual daily average air temperature range from $26^{\circ} \mathrm{C}$ to $28^{\circ} \mathrm{C}$ and yearly variation of $\pm 10^{\circ} \mathrm{C}$ to $20^{\circ} \mathrm{C}$. The average annual rainfall of $1250 \mathrm{~mm}$ spread over 7-8 months of the year and is subject to modest variation of hot and cold seasons (Opeke, 2006). The site lies in the region with modest rainfall in Kwara State as it is neighboured by the rainforest and the derived savanna in the North central (middle belt) of Nigeria. The map of Kwara state and other neighbouring states and Irepodun with headquarters in OmuAran is shown in Fig. 1. The rainy

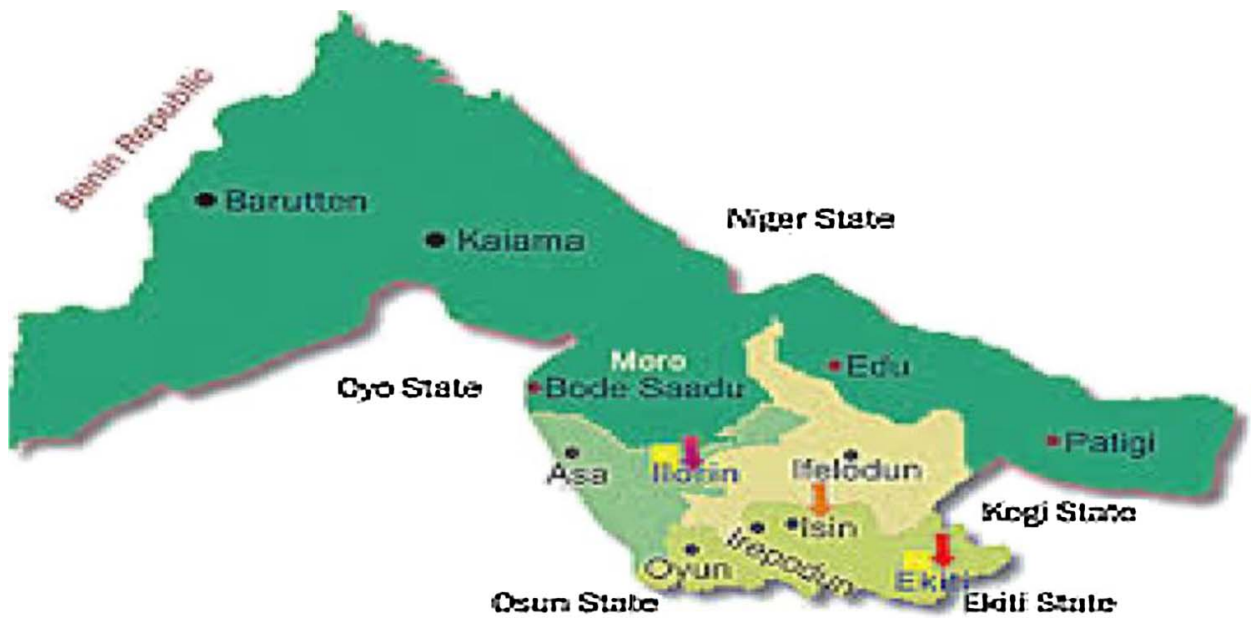

Fig. 1. Location of Irepodun LGA in Kwara State and the surrounding States. 
season commences mid March and terminates in late October. The dry season which commences in November and ends approximately midMarch is normally hotter than the rainy season. The late November to January is generally cold and dusty with Harmattan wind blow from the Sahara desert. Omu-Aran is endowed with large expanse of fertile soil of fertile soil and greenery distinctive of the guinea savanna. The soil of the area supports the growth of crops such as Pepper, Maize, Sorghum, Millet, Legumes, Vegetables, Roots and Tubers, Paddy rice, Locus beans etc. and such cash crop as Cocoa, Kolanut and Oil Palm (Omu Aran, 2015).

\subsection{Experimental procedures and measurements}

A $100 \times 50 \mathrm{~m}^{2}$ area was cleared manually at the Research and Training Farm of Landmark University, Omu-Aran, Nigeria, from which a $50 \times 30 \mathrm{~m}^{2}$ was marked out for the experiment. Pre-planting soil studies was conducted on the selected field plot. Soil samples were taken randomly from soil superficial layer $(0-15 \mathrm{~cm})$ at 36 different points, such that twelve samples were taken from every $50 \mathrm{~m} \times 10 \mathrm{~m}$ area, while ensuring a minimum of $5 \mathrm{~m}$ distance apart. Twelve soil samples collected from each of the $50 \mathrm{~m} \times 10 \mathrm{~m}$ area were thereafter bulked together as one sample, thus resulting to three bulked samples from the total area of $50 \times 30 \mathrm{~m}^{2}$ which is representative of the whole area. Soil samples collected were carefully labeled and arranged into one wooden container before being moved to the Soil Science laboratory of Landmark University for the determination of physico-chemical properties. Among the parameters determined are particle size distribution, percent Nitrogen, exchangeable Phosphorus, Potassium, Calcium and Magnesium. Also determined were soil $\mathrm{pH}$ in $\mathrm{H}_{2} \mathrm{O}$, electrical conductivity, Bulk density and Total porosity.

The lysimeter used for the experiment was made from locally sourced cylindrical polyethylene (PE) drum with a diameter of $600 \mathrm{~mm}$ and a circular cross-sectional area of $0.28 \mathrm{~m}^{2}$. The lysimeter tank has a depth of $450 \mathrm{~mm}$ with a wall thickness of $3 \mathrm{~mm}$. The lysimeter depth is appropriate as it permits normal root development for Capsicum chinense, without hinderance. The plastic material with which the lysimeter was made help to minimize heat transfer by conduction down the lysimeter walls.

Soil was obtained from a previously cultivated field at depths of $0-150 \mathrm{~mm}$ and $150-300 \mathrm{~mm}$. The soil was cautiously excavated and loaded into the lysimeter to minimize disturbance. First, gravel was placed at the bottom of the lysimeter, followed by the soil obtained at a depth of $150-300 \mathrm{~mm}$, then the soil obtained at $0-150 \mathrm{~mm}$ (the top soil). The top soil was fertilized with poultry litter. The lysimeter tank was provided with a drain tap that is made from a PVC ball valve. The drain system allows for any excess water accumulated in the inner tank to be removed, if the need arises. There is also an outer ring of metal sheet to guide the tubing in the interior while loading and to serve as a point of attachment for graduated glass tube (burette). The frame was positioned in such a way that the flat plate will not form shade over the plant in the soil tank. The hydraulic weighing lysimeter and sampled soil is shown in Fig. 2.

\subsection{Lysimeter weighing mechanism}

The hydraulic weighing lysimeter mechanism involves the use of a water filled tube (float) which is connected to a calibrated burette ( $0.1 \mathrm{~mm}$ accuracy) via a mercury manometer. A $7.5 \mathrm{~mm}$ diameter hose was used to connect the water-filled tubing to one end of the mercury manometer, while the burette was connected to the other end of the manometer. The hydraulic weighing lysimeter measures changes in weight of the lysimeter system. The soil filled lysimeter tank rests on the water-filled tubing and this act as hydraulic load cells. The pressure generated by the weight on the tubes was measured using a water-filled open-end manometer (Igbadun, 2012; Fasinmirin, 2014). All metal parts of the lysimeter setup were painted to protect it from corrosion.

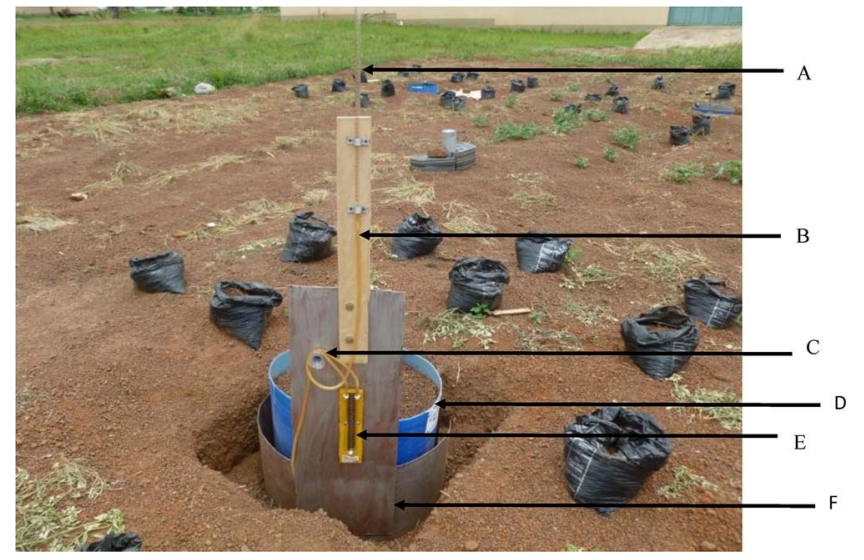

Fig. 2. The hydraulic weighing lysimeter setup.

A - graduated burette, B - connection hose between burette and manometer, $\mathbf{C}$ - hose connecting the automobile tube with the manometer, D - soil tank, E - manometer, F frame.

Daily ET measured with the lysimeters was determined as the difference between lysimeter mass losses (evaporation and transpiration) and lysimeter mass gains (irrigation and precipitation). Crop coefficient (Kc) for the different growth - stages was calculated from the ratio of daily ETc and daily ETo.

\subsection{Irrigation scheduling and soil moisture monitoring}

Soil moisture monitoring was achieved by the use of a Tensiometer which was previously calibrated as described in Fasinmirin et al. (2015). The instrument corresponding reading for critical soil moisture levels of field capacity, permanent wilting point, Management Allowable Depletion (MAD) were obtained. The quantity of water added to the crop was measured using a measuring cylinder. The time to irrigate the crop was determined by a tensiometer that was installed at the $15 \mathrm{~cm}$ depth of soil in the lysimeter. The soil in the lysimeter was irrigated to field capacity based on the tensiometer reading ( 35 centibars) the next irrigation was done at MAD of $60 \%$ which was observed to occur within 2-3 days maximum after the previous irrigation event. The irrigation amount of 51 , which is equivalent to a depth of $18 \mathrm{~mm}$ based on the surface area of soil tank was applied during each event of irrigation After calibration, the ability of the lysimeters to measure evapotranspiration was tested on a Capsicum chinense cultivated on the lysimeters, during the dry seasons of 2015/2016 and 2016/2017 (October-February each year.).

\subsection{ETo in the study area}

Weather data were collected in the site using Campbell scientific weather station. The station collects data such as; reference evaporation, solar radiation, wind speed, air temperature, dew point temperature, relative humidity, precipitation, and barometric pressure. These parameters were used to estimate the reference evapotranspiration $\mathrm{ET}_{\mathrm{o}}$ using FAO- Penman Monteith model (Allen et al., 1998) given as Eq. (2).

ETo $=\frac{0.408 \Delta\left(R_{n}-G\right)+\frac{900}{T_{a}+273} \gamma U_{2}\left(e_{s}-e_{a}\right)}{\Delta+\gamma\left(1+0.34 U_{2}\right)}$

Where:

$\mathrm{ET}_{\mathrm{o}}=$ Reference evapotranspiration $\left(\mathrm{mm} \mathrm{d}^{-1}\right) ; R_{n}=$ net radiation at the crop surface $\left(\mathrm{MJ} \mathrm{m}^{-2}\right.$ day $\left.^{-1}\right)$;

$G=$ soil heat flux density $\left(\mathrm{MJ} \mathrm{m}^{-2}\right.$ day $\left.^{-1}\right)=0$ for daily calculations of ET as G is small on daily basis; $T=$ mean daily air temperature at $2 \mathrm{~m}$ height $\left({ }^{\circ} \mathrm{C}\right) ; U_{2}=$ wind speed at $2 \mathrm{~m}$ height $\left(\mathrm{ms}^{-1}\right)$;

$e_{s}=$ saturation vapor pressure $(\mathrm{kPa}) ; e_{a}=$ actual vapor pressure 
$(\mathrm{kPa}) ;\left(e_{s}-e_{a}\right)=$ saturation vapor pressure deficit $(\mathrm{kPa}) ; \Delta=$ gradient of the saturated vapor pressure-temperature curve $\left(\mathrm{kPa}^{\circ} \mathrm{C}^{-1}\right)$, and the $\gamma=$ psychometric constant $\left(\mathrm{kPa}^{\circ} \mathrm{C}^{-1}\right)$.

The data generated by the weather station were used as input into the Crop Water Model (CROPWAT 8) in order to estimate the reference evapotranspiration, ETo.

\subsection{ETo from CLIMWAT and CROPWAT}

CLIMWAT database was used in conjunction with CROPWAT 8 model in the calculation and estimation of crop water use also known as CU. The nearest agro-climatological station to the study site selected was Ilorin, which is $75 \mathrm{~km}$ from the study site in OmuAran. The 15 year data for Ilorin station was extracted from CLIMWAT in a format suitable for its use in CROPWAT. The values obtained were described as the estimated and calculated values, which were later compared with measured values from the lysimeter.

\subsection{Soil water balance}

The expression used for the computation of daily crop water use is given as in Igbadun (2012):

$C U_{i}=P_{i}-R_{f i}-D_{i}-\left[\left(W_{i+1}-W_{i}\right) * c f\right]$

where,

$\mathrm{P}_{\mathrm{i}}=$ Rainfall amount (mm) of day $i$ collected in the rain gauge, $\mathrm{R}_{f i}=$ Runoff (mm) of day $i$.

$\mathrm{D} i=$ Drainage $(\mathrm{mm})$ of day $i, \mathrm{~W} i=$ Weight of the lysimeter soil on day $i, \mathrm{~W}_{i+1}=$ Weight of the lysimeter soil the next day at an interval of $24 \mathrm{~h}, \mathrm{CU}_{\mathrm{i}}=$ Crop water use of day $\mathrm{i}, \mathrm{cf}=\mathrm{A}$ factor converting weight to equivalent depth of water.

Any of these with minor effect are neglected and assumed zero. The differences in weight of the lysimeter tank shown by the alteration in water level in the burette thus obtained on daily basis were translated to depth of water in $\mathrm{mm} /$ day using a factor of 6.04 as reported in Igbadun (2012). This factor was based on the surface area of the lysimeter tank and the density of water.

\subsection{Statistical analysis}

The daily Kc values were analyzed by paired $t$-test and analyses of correlation using Microsoft excel Software. These were used to determine statistical differences of the measured lysimeter data from the calculated data. Soil and experimental data were subjected to statistical analysis such as mean and standard deviation, root mean square error and Mean relative error (RMSE and MRE) (Ko et al., 2009). The RMSE and MRE were given by Eqs. (4) and (5) (Piccinni et al., 2009; Abedinpour, 2015).

$\operatorname{RMSE}=\left[\frac{1}{N} \sum_{i=1}^{n}\left(C_{i}-M_{i}\right)^{2}\right]^{1 / 2}$

$\mathrm{MRE}_{\mathrm{i}}=\frac{1}{n} \sum_{i=1}^{n} \frac{\left[C_{i}-M_{i}\right]}{M_{i}} 100 \%$

where $\mathrm{C}_{\mathrm{i}}$ is the ith calculated value, $\mathrm{Mi}$ is the ith measured value and $\mathrm{n}$ is the number of data pairs. Relationship between the calculated and measured values was quantitatively evaluated using the Nash-Sutcliffe efficiency (NSE) and ratio of the RMSE to the standard deviation of measured data (SRS) (Abedinpour, 2015). The NSE, and RSR are given by the following equations as Eqs. (6) and (7) respectively.

$\mathrm{NSE}=1-\frac{\sum_{i=1}^{n}\left(E T_{\text {obs }}-E T_{\text {cal }}\right)^{2}}{\sum_{i=1}^{n}\left(E T_{\text {obs }}-E T_{\text {mean }}\right)^{2}}$
$\mathrm{SRS}=\frac{\sqrt{\sum_{i=1}^{n}\left(E T_{o b s}-E T_{\text {cal }}\right)^{2}}}{\sqrt{\sum_{i=1}^{n}\left(E T_{\text {obs }}-E T_{\text {mean }}\right)^{2}}}$

where:

$\mathrm{ET}_{\text {cal }}$ - calculated ETc by FAO-56, $\mathrm{ET}_{\text {obs }}$ - observed/measured ETc by lysimeter, $\mathrm{ET}_{\text {mean }}$ - average daily $\mathrm{ET}_{\mathrm{obs}}$ over the season. Also, graphical analysis of the weather parameters, evapotranspiration and crop factor curve were presented to enhance interpretation of trends and characteristics of the data collected.

\section{Results and discussions}

\subsection{Physicochemical properties of the soil in the study area}

The result of physicochemical properties of the soil in the study area is presented in Table 1.

The data regarding physical and chemical composition of soil revealed that the soil of the plot was Loamy sand, containing $78.9 \%$, $8.22 \%$ and $12.88 \%$ of sand, silt and clay respectively. The nutrient content was found to be low but improved by adding organic manure to raise its level.

\subsection{Calculated and observed ETC and ETo}

The Agro-meteorological data from the study site and Ilorin (reference station) is shown in Table 2 . The predicted data was slightly higher than the measured data for the study site. The difference is accounted for by the location of the study site relative to the reference

Table 1

Mean (STD) of Soil Physical and Chemical Properties of the study site.

\begin{tabular}{ll}
\hline Parameters & Mean (STD) \\
\hline Sand (\%) & $78.90( \pm 0.12)$ \\
Silt (\%) & $8.22( \pm 0.02)$ \\
Clay (\%) & $12.88( \pm 0.34)$ \\
Textural Class & Loamy sand \\
Bulk density $\left(\mathrm{g} / \mathrm{cm}^{3}\right)$ & $0.714( \pm 0.30)$ \\
Total porosity $(\%)$ & $43.50( \pm 1.94)$ \\
$\mathrm{pH}\left(\mathrm{H}_{2} 0\right)$ & $5.80( \pm 1.06)$ \\
EC $\left.(\mathrm{dsm})^{-1}\right)$ & $7.80( \pm 1.24)$ \\
$\mathrm{N}(\%)$ & $0.10( \pm 0.02)$ \\
$\mathrm{K}\left(\mathrm{Mol} \mathrm{Kg}{ }^{-1}\right)$ & $0.88( \pm 0.21)$ \\
$\mathrm{Ca}\left(\mathrm{Mol} \mathrm{Kg}^{-1}\right)$ & $8.01( \pm 0,43)$ \\
$\mathrm{P}(\%)$ & $8.67( \pm 0.78)$ \\
$\mathrm{Mg}\left(\mathrm{Mol} \mathrm{Kg}^{-1}\right)$ & $2.00( \pm 0.87)$ \\
\hline
\end{tabular}

Table 2

Agrometrological data from the study site and Ilorin reference station.

\begin{tabular}{|c|c|c|c|c|c|c|}
\hline \multirow[b]{2}{*}{ Months } & \multicolumn{3}{|c|}{$\begin{array}{l}\text { Annual Measured ETo } \\
\text { (mm/day) }\end{array}$} & \multirow{2}{*}{$\begin{array}{l}\text { Average } \\
\text { mm day }^{-1}\end{array}$} & \multirow{2}{*}{$\begin{array}{l}\text { S.E } \\
\pm \\
\pm\end{array}$} & \multirow{2}{*}{$\begin{array}{l}\text { Calculated ETo } \\
\text { (Ilorin) } \\
\text { mm day }^{-1}\end{array}$} \\
\hline & 2015 & 2016 & 2017 & & & \\
\hline January & 4.03 & 4.09 & 3.67 & 3.93 & 0.23 & 4.76 \\
\hline February & 4.13 & 4.19 & 4.16 & 4.16 & 0.03 & 5.68 \\
\hline March & 4.3 & 4.32 & 4.56 & 4.39 & 0.14 & 6.12 \\
\hline April & 4.45 & 4.38 & 4.32 & 4.38 & 0.07 & 5.34 \\
\hline May & 3.71 & 3.83 & 3.75 & 3.76 & 0.06 & 4.76 \\
\hline June & 3.21 & 3.19 & & 3.20 & 0.01 & 4.16 \\
\hline July & 2.7 & 2.52 & & 2.61 & 0.13 & 3.63 \\
\hline August & 2.43 & 2.48 & & 2.45 & 0.04 & 3.53 \\
\hline September & 2.74 & 2.40 & & 2.57 & 0.24 & 3.62 \\
\hline October & 3.06 & 3.45 & & 3.25 & 0.28 & 4.03 \\
\hline November & 3.83 & 3.85 & & 3.84 & 0.01 & 4.48 \\
\hline December & 4.27 & 3.65 & & 3.96 & 0.44 & 4.49 \\
\hline Average & 3.57 & 3.53 & & & & 4.55 \\
\hline
\end{tabular}




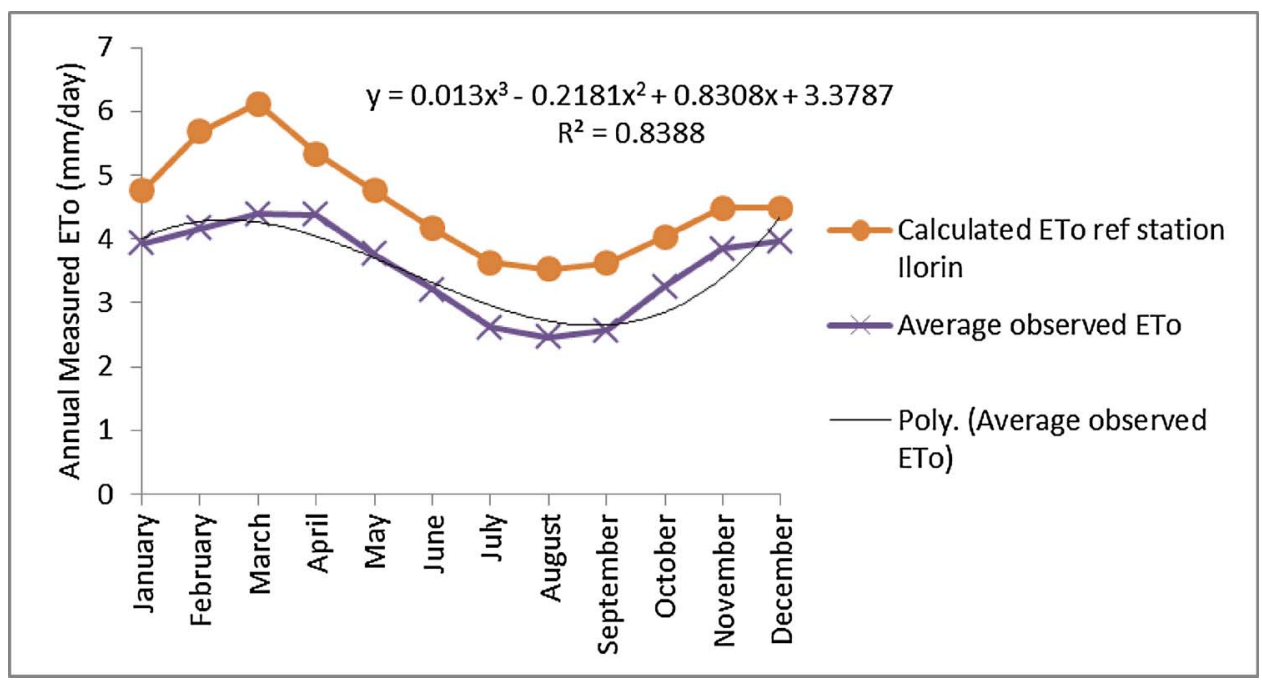

Fig. 3. Comparison between calculated and observed ETo values.

station. The study site is closer to the derived savanna while Ilorin is in the Southern Guinea Savannah Ecological Zone of Nigeria which is northward. The result of this research agrees closely with the findings of Adeniran et al. (2010) in which ETo varied from 3.4 to $4.8 \mathrm{~mm}$ day $^{-1}$.

The comparison between calculated and lysimeter observed ETo values and the trend is shown in Fig. 3. The calculated ETo for the Ilorin reference station with air distance of $75 \mathrm{~km}$ was found to be higher for all months observed. This is expected as the study site is in the fringe of rainforest and derived savanna with humid condition compare to the reference station (Ilorin) deeply located in the guinea savanna vegetative belt (Iroye, 2017).

\subsection{Calculated versus observed Kc}

The monthly crop coefficient and evapotranspiration data from the study site and Ilorin reference station is shown in Table 3. The Kc varied for the months under consideration. The Kc was obtained from the ratio of both ETc and ETo. ETo was obtained from the weather station installed within the study area. The adjustment of the Kc shows that crop posseses inherent properties which make it adapt and adjust to the environmental factors. The relationship between the lysimeter observed and calculated $\mathrm{Kc}$ is shown in Fig. 4.

\subsection{Measured crop coefficient Kc for Capsicum chinense}

The Kc values for initial, mid and end stages of growth of Capsicum chinense were read from Fig. 5. A polynomial equation for the lysimeter measured Kc in shown in Fig. 5 as Kc curve. The quadratic crop coefficient value as in (Ayars and Hutmacher, 1994; Sammis and Wu, 1985; Stegman, 1988) were found to be $0.32-0.7,1.02-1.45$ and $0.76-0.9$ respectively. These values were slightly different from the values suggested by FAO-56 (Allen et al., 1998) which are 0.6, 1.05 and 0.9 for $\mathrm{Kc}_{\text {ini }}, \mathrm{Kc}_{\text {mid }}$ and $\mathrm{Kc}_{\text {end }}$ respectively. The linear relationship between lysimeter measured Kc and calculated Kc is shown in Fig. 6.

\subsection{Consumptive use of Capsicum chinense}

The daily measured Consumptive use values for Capsicum chinense in the lysimeters for the growing season (October to February) are recorded and analysed in Table 4.

From Table 4 the seasonal $\mathrm{CU}$ of Capsicum chinense was $580.01 \pm 53.9 \mathrm{~mm}$ while the reference evapotranspiration increased from $3.26 \mathrm{~mm} /$ day in October to $4.19 \mathrm{~mm} /$ day in February. The crop factor increased from 0.7 in October to attain its peak of 1.5 in January during the growing season before decreasing to 0.9 in February. Likewise the daily crop water need was $2.28 \mathrm{~mm}$ /day in October to reach its

Table 3

The monthly crop coefficient and evapotranspiration data from the study site and Ilorin reference station.

\begin{tabular}{|c|c|c|c|c|c|c|c|c|c|c|}
\hline \multirow[b]{3}{*}{ Days } & \multirow[b]{3}{*}{ Months } & \multirow{2}{*}{\multicolumn{3}{|c|}{ Ilorin(Calculated) }} & \multirow{2}{*}{\multicolumn{3}{|c|}{ Omuaran (Measured) }} & \multicolumn{3}{|c|}{ Omuaran (Measured) } \\
\hline & & & & & & & & & $\underline{2016 / 2}$ & \\
\hline & & Ke & $\begin{array}{l}\text { ETo } \\
\text { (mm/day) }\end{array}$ & $\begin{array}{l}\text { ETc } \\
\text { (mm/day) }\end{array}$ & Kc & $\begin{array}{l}\text { ETo } \\
\text { (mm/day) }\end{array}$ & $\begin{array}{l}\text { ETc } \\
\text { (mm/day) }\end{array}$ & Ke & $\begin{array}{l}\text { ETo } \\
\text { (mm/day) }\end{array}$ & $\begin{array}{l}\text { ETc } \\
(\mathrm{mm} / \mathrm{day})\end{array}$ \\
\hline 1 to31 & October & 0.60 & 4.03 & 2.41 & 0.7 & 3.06 & 2.16 & 0.6 & 3.45 & 2.05 \\
\hline 32 to 62 & November & 1.05 & 4.48 & 4.70 & 0.5 & 3.83 & 2.01 & 0.6 & 3.85 & 2.15 \\
\hline 63 to94 & December & 1.05 & 4.49 & 4.71 & 1.2 & 4.27 & 5.20 & 1.5 & 3.65 & 5.65 \\
\hline 95 to 126 & January & 0.90 & 4.76 & 4.28 & 1.5 & 4.09 & 5.98 & 1.6 & 3.67 & 5.82 \\
\hline \multicolumn{11}{|l|}{127 to } \\
\hline 156 & February & 0.90 & 5.68 & 5.11 & 0.9 & 4.19 & 3.84 & 0.9 & 4.19 & 3.64 \\
\hline
\end{tabular}




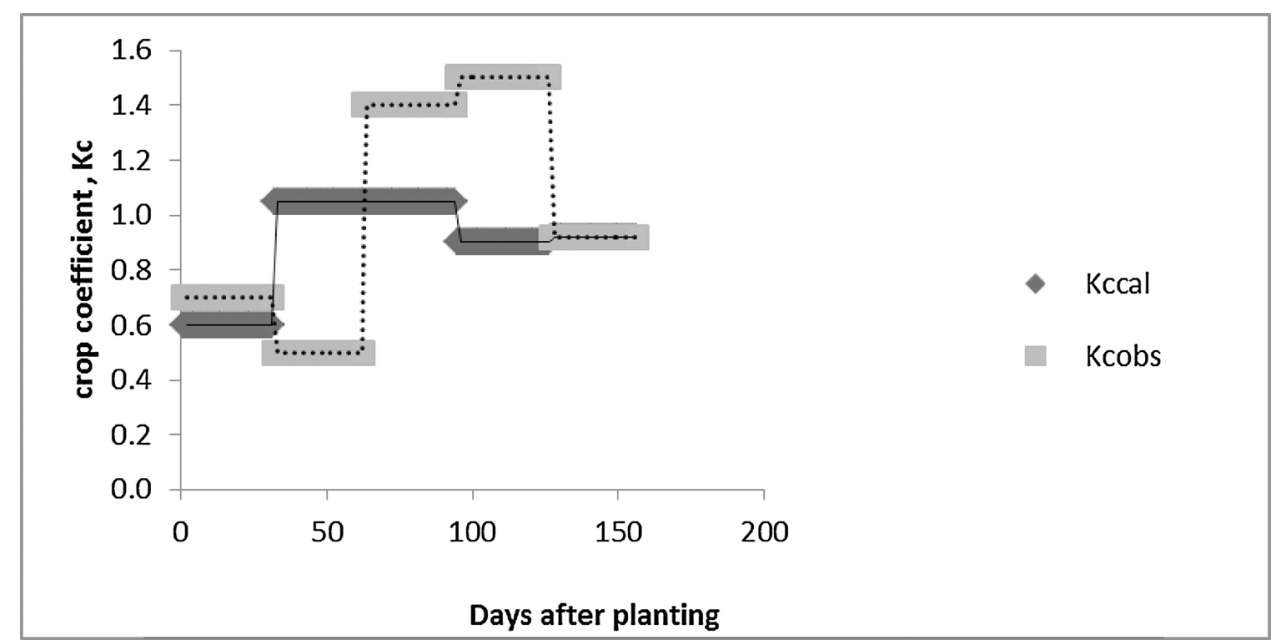

Fig. 4. The relationship between the observed and calculated Kc.

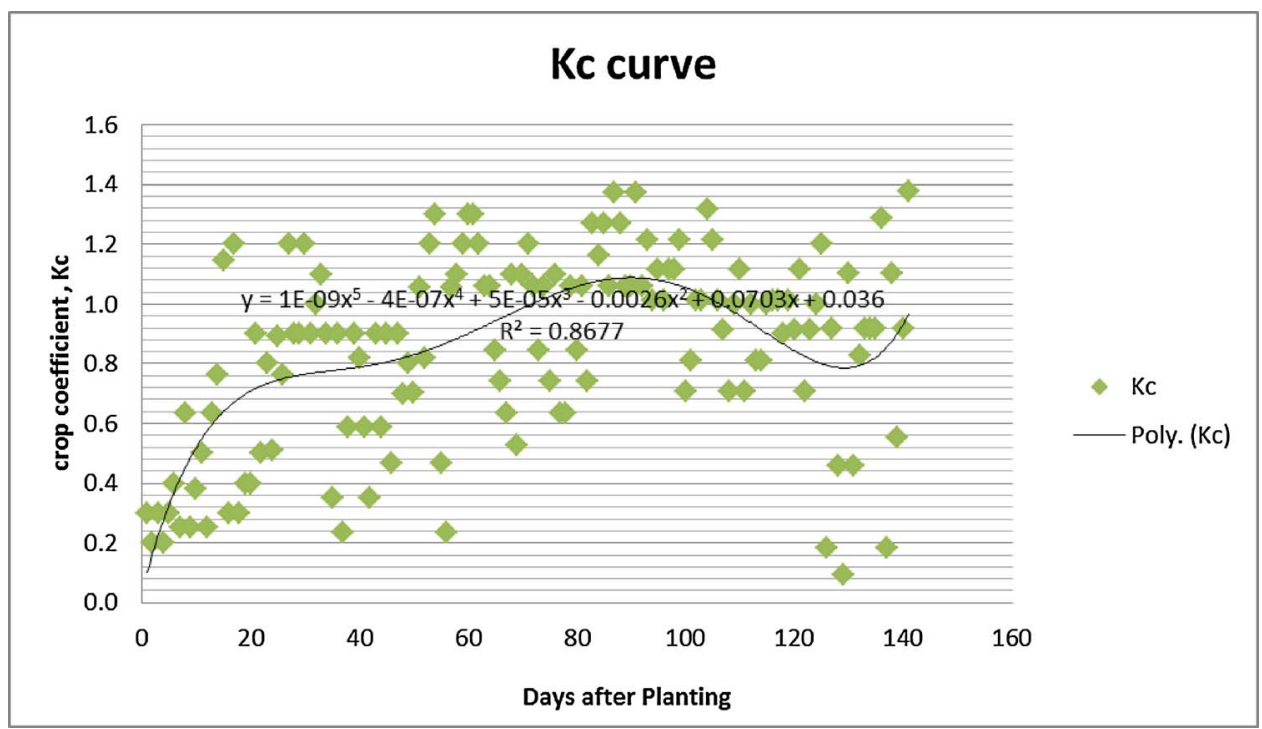

Fig. 5. Lysimetric Kc curve for Capsicum chinense in OmuAran.

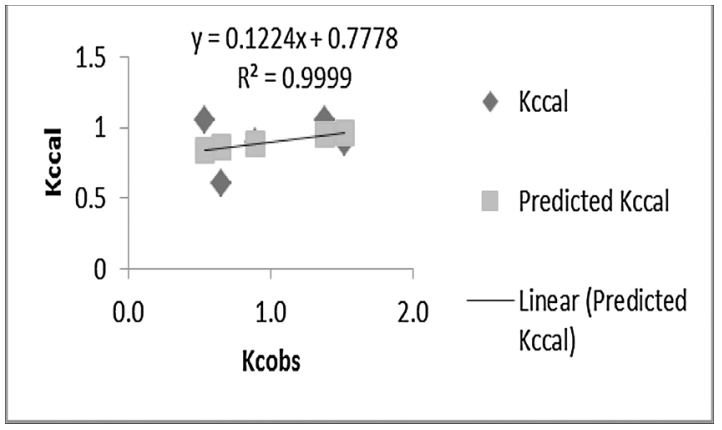

Fig. 6. Linear relationship between Lysimeter $\mathrm{Kc}\left(\mathrm{Kc}_{\mathrm{obs}}\right)$ and calculated $\mathrm{Kc}\left(\mathrm{Kc}_{\mathrm{cal}}\right)$.

peak at $5.82 \mathrm{~mm} /$ day in January during its growing season before decreasing to $3.77 \mathrm{~mm} /$ day in February. The monthly crop water need for pepper was found to be $68.36 \mathrm{~mm} / \mathrm{month}$ in October to attain its peak of $166.32 \mathrm{~mm} / \mathrm{month}$ in December before declining to $113.13 \mathrm{~mm}$ / month in February.
Table 4

Observed value of ETc for the growing period in the study site.

\begin{tabular}{llllll}
\hline Months & October & November & December & January & February \\
\hline${ }^{\mathrm{a}} \mathrm{ET}_{\mathrm{o}}\left(\mathrm{mm} \mathrm{d}^{-1}\right)$ & 3.26 & 3.84 & 3.96 & 3.88 & 4.19 \\
$\mathrm{G}$. Stages & Initial & Dev. & Dev/Mid & Mid & Late \\
${ }^{\mathrm{b}} \mathrm{Kc}$ & 0.7 & 0.5 & 1.4 & 1.5 & 0.9 \\
$\mathrm{ET}_{\mathrm{c}}\left(\mathrm{mm} \mathrm{d}^{-1}\right)$ & 2.28 & 1.92 & 5.54 & 5.82 & 3.77 \\
${ }^{\mathrm{c}} \mathrm{ET}_{\mathrm{c}}\left(\mathrm{mm} \mathrm{mth}^{-1}\right)$ & 68.36 & 57.6 & 166.32 & 174.6 & 113.13 \\
\hline
\end{tabular}

a Average values for the year 2015/16 and 2016/17 in the study site.

b Observed Kc value of ETc for the growth stages.

${ }^{\mathrm{c}}$ Monthly evapotranspiration values in the study site G-Stage (growth stage).

\subsubsection{Evaluation statistics}

The result of the evaluation statistics adopted in the study was presented in Table 5.

Generally, the NSE values obtained from the analysis of the results show that except for the late stage Kc values which was found to be unity or perfect fit, the other NSE values were found to have the 
Table 5

Experimental results during the planting period.

\begin{tabular}{lllllllll}
\hline Days & Months & $\mathrm{Kc}_{\mathrm{cal}}$ & $\mathrm{Kc}_{\mathrm{obs}}$ & $\Delta \mathrm{Kc}$ & $\mathrm{RMSE}$ & $\mathrm{MRE}$ & NSE & RSR \\
\hline $1-31$ & October & 0.6 & 0.7 & 0.1 & 1.2000 & 14.20 & -3.01 & 1.17 \\
$32-62$ & November & 1.05 & 0.5 & -0.5 & 0.5300 & 100.00 & -173.61 & 1.47 \\
$63-94$ & December & 1.05 & 1.4 & 0.3 & 1.0012 & 21.40 & -416.56 & 2.63 \\
95-126 & January & 0.9 & 1.5 & 0.6 & 1.0021 & 40.00 & -625.73 & 4.77 \\
$127-156$ & February & 0.9 & 0.9 & 0.0 & 0.7923 & 0.00 & 1.00 & 1.22
\end{tabular}

$\mathrm{Kc}_{\mathrm{cal}}$ - Calculated (model) crop coefficient; $\mathrm{Kc}_{\mathrm{obs}}$ - Observed/Measured crop coefficient; $\Delta$ Kc - difference in crop coefficient; RMSE - Root mean square error; MRE - Mean relative error; NSE - Nash-Sutcliffe coefficient; RSR - ratio of the root mean square error to the standard deviation of measured data.

efficiency value which is all less than zero. This means that the observed mean is a better predictor than the calculated mean from the model. The $(+)$ values shows over-estimation and $(-)$ shows under estimation with respect to the measured values. The closest NSE value to 1 was that of the initial stage which was -3.01 , the farthest being -625.73 was the Kc for the mid stage. This agrees with the findings of Ko et al. (2009) and Abedinpour (2015) who concluded that regional Kc determination is inevitable.

The RMSE value for the development stage was low, which indicates that theoretical values obtained was better than observed value. MRE is a measure of how accurate a measurement is compared to the true value. It compares the observed values to calculated values. The obtained values show that the calculated Kc for initial stage differ slightly from that of the measured value by $14.2 \%$, the difference in that of development stage was $100 \%$, the mid stages were 21 and $40 \%$ respectively. There was no difference in the end/last stage MRE values.

A $t$-test shows that the mean $\mathrm{Kc}_{\text {cal }}$ was significantly different from the $\mathrm{Kc}_{\mathrm{obs}}$ in the Lysimeter experiment $(\mathrm{p}<0.05)$.

\section{Conclusions}

Consumptive Use of irrigated Capsicum chinense was estimated using mini hydraulic weighing lysimeter. The average daily water use obtained compared very closely with values obtained using CROPWAT 8.0, which implies that the CROPWAT 8.0 is effective in Irrigation scheduling. CROPWAT 8.0 is an effective tool for irrigation scheduling where local data is not available. The Kc values for initial, mid and end stages of growth of Capsicum chinense were found to be 0.32-0.7, $1.02-1.45$ and $0.76-0.9$, respectively. These values were slightly different from the values calculated from FAO-56 suggested method (Allen et al., 1998) for a closely related pepper in the list, which are 0.6, 1.05 and 0.9 for $\mathrm{Kc}_{\text {ini }}, \mathrm{Kc}_{\mathrm{mid}}$ and $\mathrm{Kc}_{\mathrm{end}}$ respectively for Bell pepper (not Capsicum chinense). The results also revealed that the ETc of the Capsicum chinense crop increases during the development and mid stages. Hence, the crop water use is highest during the crop growth mid stage. The seasonal CU of Capsicum chinense was $580.01 \mathrm{~mm}$, while the reference evapotranspiration increased from $3.26 \mathrm{~mm} \mathrm{day}^{-1}$ in October to $4.19 \mathrm{~mm} \mathrm{day}^{-1}$ in February. It was also deduced that Kc values for
Capsicum chinense is different from that of bell pepper recommended for use for all types of pepper.

\section{Conflict of interest}

The authors declared that there is no any conflict of interests.

\section{Acknowledgements}

We gratefully acknowledge the critical comments and corrections of respected reviewers whose comments and corrections improved the execution of this work considerably. We also thank the editor and the anonymous reviewers for their valuable comments.

\section{References}

ASCE-EWRI, 2005. The ASCE Standardized Reference Evapotranspiration Equation. Environment and Water Resources Institute (EWRI) of ASCE, Standardization of Reference Evapotranspiration Task Committee Final Rep.. http://www.kimberly. uidaho.edu/water/asceewri/ascestzdetmain2005.pdf.

Abedinpour, M., 2015. Evaluation of growth-stage-specific crop coefficients of maize using weighing lysimeter. Soil Water Res. 10, 99-104.

Abrisquetaa, I., Abrisquetaa, J.M., Tapiac, L.M., Munguíad, J.P., Conejeroa, W., Veraa, J., Ruiz-Sáncheza, M.C., 2013. Basal crop coefficients for early-season peach trees. Agric. Water Manag. 121, 158-163. www.elsevier.com/locate/agwat.

Adekiya, A.O., Agbede, T.M., Aboyeji, C.M., 2015. Effect of time of siam weed (Chromolaena odorata) mulch application on soil properties, growth and tuber yield of white yam. N. Y. Sci. J. 8 (9), 58-64.

Adeniran, K.A., Amodu, M.F., Amodu, M.O., Adeniji, F.A., 2010. Water requirements of some selected crops in Kampe dam irrigation project. Aust. J. Agric. Eng. 1 (4), 119.

Allen, R.G., Smith, M., Perrier, A., Pereira, L.S., 1998. Crop Evapotranspiration, Guidelines for Computing Crop Water Requirements. FAO Irrigation and Drainage Paper No. 56. Food and Agriculture Organization of the United Nations, Rome, Italy.

Ayars, J.E., Hutmacher, R.B., 1994. Crop coefficients for irrigating cotton in the presence of groundwater. Irrig. Sci. 15, 45-52.

Fasinmirin, T.J., Reichert, J.M., Oguntunde, P.G., Ajayi, A.E., 2015. Greenhouse evapotranspiration and crop factor of Amaranthus cruentus grown in weighing lysimeters. Afr. J. Agric. Res. 10 (34), 3453-3461.

Fasinmirin, J.T., 2014. Soil physical properties and yield response of melon (Colocynthis citrullus L.) to different tillage treatments in a humid rainforest soil of Akure, Nigeria. In: Proceedings of the International Soil Tillage Research Organisation (ISTRO) Nigeria Symposium. Akure 2014 November 3-6, Akure, Nigeria. pp. 207-217.

Fisher, D.K., 2012. Simple weighing lysimeters for measuring evapotranspiration and developing crop coefficients. Int. J. Agric. Biol. Eng. 5 (3), 35-43.

Igbadun, H.E., 2012. Estimation of crop water use of rain-fed maize and groundnut using mini lysimeters. Pac. J. Sci. Technol. 13 (1), 527-535.

Iroye, K.A., 2017. Correlating pattern of river discharge with degree of urbanization in sub-catchments of River Asa in Ilorin, Nigeria. Ethiop. J. Environ. Stud. Manage. 10 (2), 251-261.

Ko, J., Piccinni, G., Marek, T., Howell, T., 2009. Determination of growth-stage-speciffic crop coefficients (Kc) of cotton and wheat. Agric. Water Manage. 96, 1691-1697. http://dx.doi.org/10.1016/j.agwat.2009.06.023.

Omu Aran, 2015. Retrieved from www.Omuaran.com, on 20th September, 2016.

Opeke, L.M., 2006. Essential Food Crops, 2nd ed. Spectrum Book Ltd., Ibadan, Nigeria.

Piccinni, G., Ko, J., Marek, T., Howell, T., 2009. Determination of growth-stage-specific crop coefficients (Kc) of maize and sorghum. Agric. Water Manage. 96 (12), 1698-1704. http://dx.doi.org/10.1016/j.agwat.2009.06.024.

Sammis, T.W., Wu, I.P., 1985. Effect of drip irrigation design and management on crop yield. Trans. ASAE 28, 832-838.

Stegman, E.C., 1988. Corn crop curve comparisons for the central and northern great plains of the U.S. Trans. ASAE 4, 226-233. 